\title{
Effects of urban trees on local outdoor microclimate: synthesizing field measurements by numerical modelling
}

\author{
Yafei Wang ${ }^{1,2}$ - Frank Bakker ${ }^{2}$ - Rudolf de Groot $^{1}$ • \\ Heinrich Wortche ${ }^{2} \cdot$ Rik Leemans ${ }^{1}$
}

Published online: 22 March 2015

(C) The Author(s) 2015. This article is published with open access at Springerlink.com

\begin{abstract}
In this study, we investigated the effects of trees on the local urban microclimate and human thermal comfort under different local weather conditions, in a small urban area in Assen, the Netherlands. In both summer and winter, continuous air temperature and relative humidity measurements were conducted at five selected sites having obviously different environmental characteristics in tree cover. Measurements demonstrated that in summer the microclimatic conditions at each observation site showed significant differences. The cooling effects of trees on clear and hot days were two times higher than on cloudy and cold days. In winter, air temperature was slightly reduced by the evergreen trees, and weather conditions did not cause a notable change on performance of trees on the microclimate. ENVI-met, a threedimensional microclimate model was used to simulate the spatial distribution of temperature and humidity. After selecting representative days, we simulated the study site as it currently is and for a situation without trees. Spatial differences of trees' effects were found to vary strongly with weather conditions. Furthermore, human thermal comfort is indicated by the Predicted Mean Vote model. During the hottest hours, trees improved the thermal comfort level via reducing 'very hot' and 'hot' thermal perception by about $16 \%$ on clear days and $11 \%$ on cloudy days. Generally, our findings demonstrate that urban microclimate and human thermal comfort convincingly varies in close geographical proximity. Both are strongly affected by the presence of local trees. Weather conditions play an important role on the trees' performance on the summer-time microclimate.
\end{abstract}

Keywords Trees · Outdoor thermal comfort - Urban microclimate $\cdot$ Numerical simulation · Field Measurements

Yafei Wang

yafeiwang@incas3.eu

1 Environmental System Analysis group, Wageningen University, P.O. Box 47, 6700 AA Wageningen, The Netherlands

2 INCAS3, P.O. Box 797, 9400 AT Assen, The Netherlands 


\section{Introduction}

Urban sprawl accompanied with the decline of natural landscapes, is a major driver of changes in urban microclimate (Millennium Ecosystem Assessment 2005). In the past decades, several studies proved that urban greenery, especially trees, can positively affect outdoor microclimate and moderate the urban heat island effect in the summer (Frelich 1992; Akbari et al. 2001; Bonan 2002; Berry et al. 2013; Skoulika et al. 2014). The shade of trees or taller shrubs attenuate solar radiation and prevent the night's heat flow from the surface to the sky, thereby altering local climates and comfort levels (Akbari 2002; Heisler and Grant 2000; Mcpherson et al. 1988). In addition, evaporation and transpiration from vegetation could lower air temperature and increase moisture content (Taha et al. 1991; Chen and Jim 2008; Huang et al. 2008; Park et al. 2012; Shahidan et al. 2012; Hedquist and Brazel 2014; Middel et al. 2014). Trees reduce wind velocities and consequently reduce heat convection (Shahidan et al. 2012; Hedquist and Brazel 2014). Previous studies typically measured or modeled several representative but unconnected landscapes (e.g., Huang et al. 2008; Shahidan et al. 2012; Middel et al. 2014). Additionly, the influence of weather conditions, which affect the mediating effects of trees (Morakinyo et al. 2013; c.f. Wang et al. 2014), are poorly understood.

This study aims to enhance the understanding of the role of trees on local microclimate. We continuously measured temperature and humidity and combined them with numerical modelling in a small urban area during summer and winter. We determined the spatial variations in temperature and humidity due to the distribution of trees in a local area. Additionally, by classifying the actual weather conditions during the observation period, the cooling effects of trees under different weather conditions can be established.

\section{Materials and methods}

Two approaches, field measurements and numerical modeling, were used in this study. We empirically analyzed continuous summer and winter field measurements (temperature and humidity) at five sites in the Dutch city of Assen, that together characterize the heterogeneity of the small urban area (e.g., no tree cover, high tree cover and shading from buildings). The effects of trees on the microclimate at these sites were analyzed under varies synoptic weather conditions. We clustered weather conditions of monitoring days. The days representing the weather conditions of 'clear and hot' and 'cloudy and cool' in summer and 'clear and mild' and 'cloudy and cold' in winter were used for the analysis. Since the effects of geometric factors (e.g., orientation and location of buildings and trees) on temperature and humidity distributions are complex and cannot completely be determined from our spot measurements, we combined the empirical data with comprehensive computer simulations using the ENVI-met software. The simulated days were selected at random from 'clear and hot' and 'cloudy and cool' days in summer and 'clear and mild' and 'cloudy and cold' days in winter days. Using the simulation model, the relationship between tree location, size and shape, and the temperature and humidity distribution are explored. Further, the simulations allowed us to relate variations in microclimate due to trees and buildings with human comfort. 


\section{Sites and observation period}

Assen, the capital of the province of Drenthe, generally has a moderate maritime climate. July and August are the warmest months and January and February are the coldest months of the year. The leaf-off period is normally from November to March. ${ }^{1}$ Our study was conducted in a $3600 \mathrm{~m}^{2}$ area (latitude: $53^{\circ} 0$ ' 0 " $\mathrm{N}$, longitude of $6^{\circ} 55^{\prime} 00^{\prime} \mathrm{E}$ ) in the built-up area of Assen (Fig. 1). The total surface cover fractions for trees, buildings, shrub, grass, hedge and pavement are $5,14,2,41,1$, and $37 \%$, respectively. Two thirds of the trees are conifer evergreen trees. The field measurements were conducted in one summer (from $20^{\text {th }}$ July- $31^{\text {st }}$ August, 2013) and one winter (from $1^{\text {st }}$ January- $28^{\text {th }}$ February, 2014).

\section{Field measurements}

Field measurements were conducted to investigate the (spatial and temporal) temperature and humidity differences among sites with different environmental characteristics under different weather conditions.

\section{Measurement items}

Five air temperature (Ta) and relative humidity $(\mathrm{RH})$ stations (6382OV Davis Temp/ Hum Station, accuracy: $\pm 0.5{ }^{\circ} \mathrm{C} / \pm 3 \%$ ) were mounted in locations with different environmental characteristics, at the same height of $1.5 \mathrm{~m}$ above ground. The location of these stations are illustrated in Fig. 2. In addition, one weather station (6162 Davis Wireless Vantage Pro2 Plus) was placed above the best exposed part of the tallest building (approximately $10 \mathrm{~m}$ above the ground) within study area. All the temperature and humidity sensors were placed in radiation shields to minimize the effects of radiation. Data from all stations is simultaneously acquired every ten minutes and stored in a database through a data receiver (6318 EU Davis Weather Envoy 8X) and data logger (6510 USB Davis USB Datalogger). Data from the weather station (including Ta, RH, solar radiation, rainfall and wind velocity and direction) was recorded every minute.

\section{Data analysis methods}

Each observation day was divided into daytime and night time to explore the different trees' effects (e.g., providing shade during daytime, blocking heat flow at night). In the summer, daytime was defined from 06:00 to 21:00, while in the winter, daytime ran from 8:30 am to 17:30 pm.

For each observation period (summer and winter), we tested whether specific parameters of the microclimate differed and varied and ranged differently among the five observation sites. Hence, a one-way Multivariate Analysis of Variance (MANOVA) test was performed on the temperature and humidity data. The diurnal values (i.e., maximum, minimum and average value, changing rate (CR) and Range) for $\mathrm{Ta} / \mathrm{RH}$ were modelled as dependent variables, while the observation sites were the independent, fixed variables. Maximum, minimum and average $\mathrm{Ta} / \mathrm{RH}$ strongly related

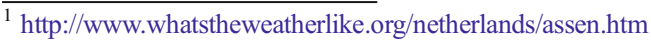




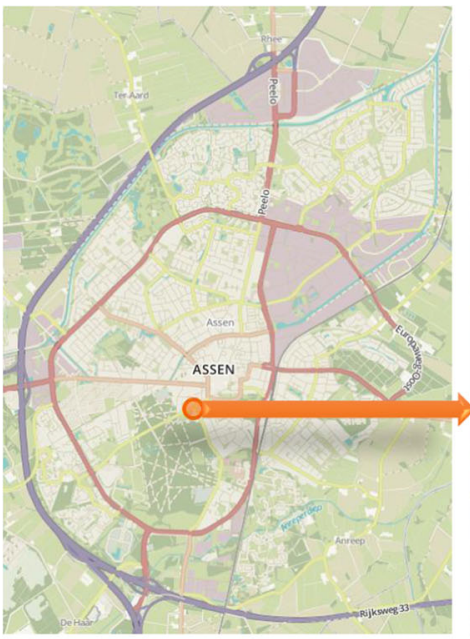

a

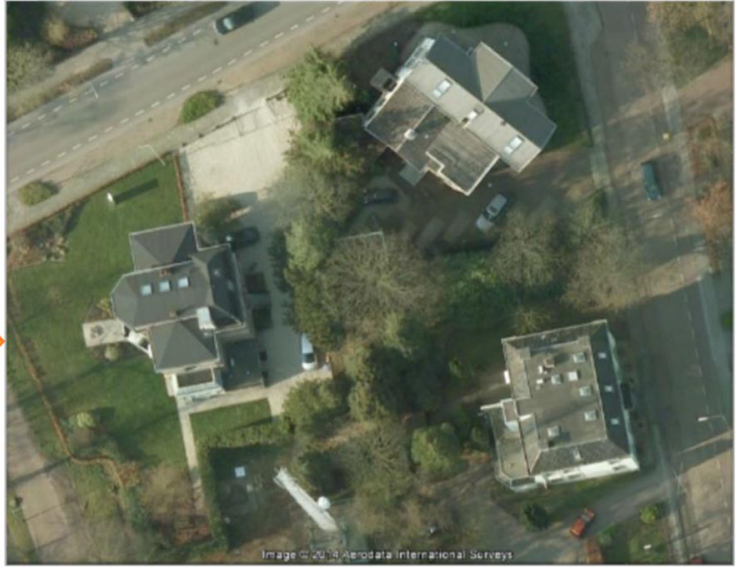

b

Fig. 1 The City of Assen, The Netherlands (a); the study area is located in an urban area close to the city center (b). Source: screenshot of OpenStreetMap (OSM) and Google Earth. http://en.wikipedia.org/wiki/ OpenStreetMap

to outdoor comfort and were therefore also included in the analysis. However, the microclimate in Assen varied greatly in both summer and winter, and the variance of $\mathrm{Ta} / \mathrm{RH}$ during the observation periods at the specific sites was large. Hence, the MANOVA test on the maximum, minimum and average $\mathrm{Ta} / \mathrm{RH}$ among the observation

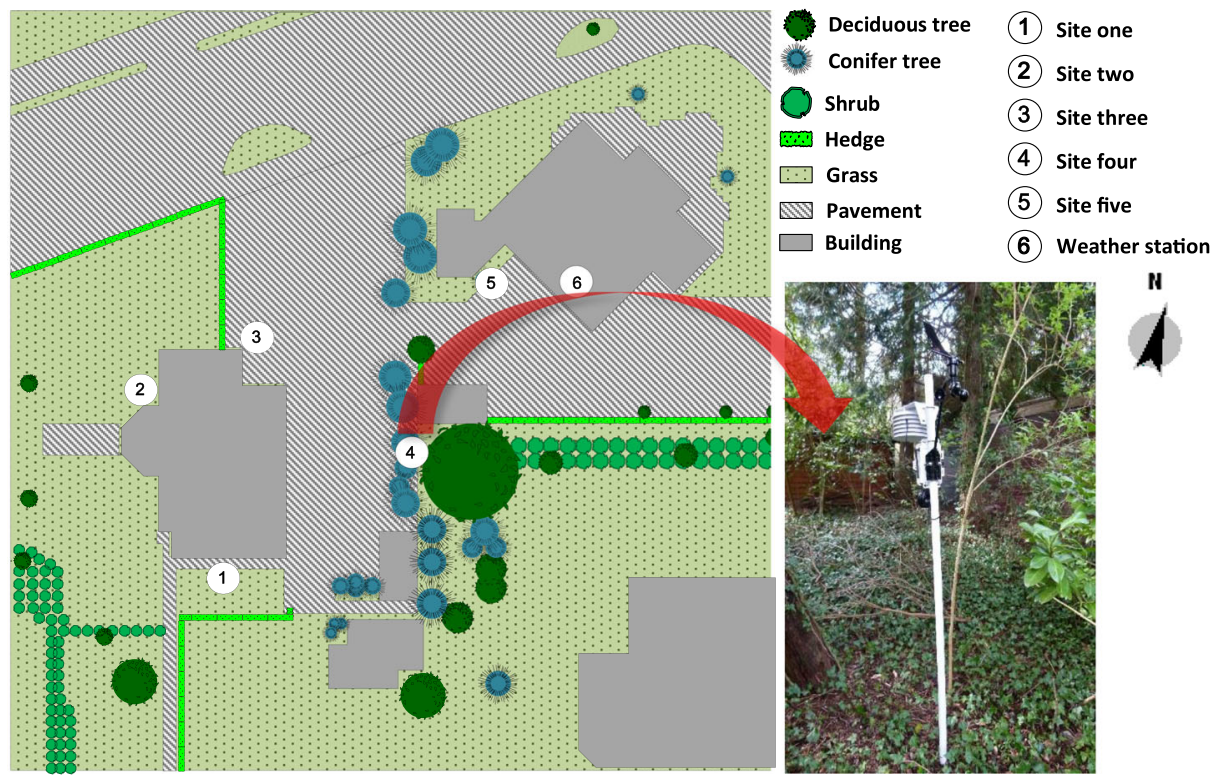

- Definition: a combination of sitemap made in "Visio 2013" (Left) and photograph (Right)

Fig. 2 The location of the observation sites in the study area. The bottom-right image shows an example of a temperature/humidity station, combined with an anemometer 
sites might be obscured. We therefore calculated the differences between these factors and their mean values for all sites $D(t)$. A one-way MANOVA was then performed for these differences.

$$
D(t)_{d j}=\max / \min / \operatorname{average}_{i}\left(x_{d j i}\right)-\frac{1}{M} \sum_{j=1}^{M} \max / \min / \operatorname{average}_{i}\left(x_{d j i}\right)
$$

Where $t$ stands for maximum, minimum and average Ta/RH, and $x$ stands for Ta and RH.

In addition, $\mathrm{CR}$ and Range are also important because they implies the level and amount of $\mathrm{Ta} / \mathrm{RH}$ change along a day regardless of average temperature or seasons. The one-way MANOVA, Tukey post-hoc tests helped to compare the different observation sites. For all our statistical analysis, significance was defined as a P value less than 0.05 . The CR and Range are expressed as:

$$
\begin{gathered}
C R_{d j}=\frac{\sum_{i=1}^{N}\left[\max _{i}\left(x_{d j i}\right)-x_{d j i}\right]}{N\left[\max _{i}\left(x_{d j i}\right)-\min _{i}\left(x_{d j i}\right)\right]} \\
\text { Range }_{d j}=\max _{i}\left(x_{d j i}\right)-\min _{i}\left(x_{d j i}\right)
\end{gathered}
$$

Where $x$ stands for Ta and RH, with the different parameters defined below:

$\mathrm{j} \quad$ index of observation site $(\mathrm{j}=1, \ldots, \mathrm{M}), \mathrm{M}=5$

$\mathrm{M}$ total number of observation sites

$\mathrm{d}$ index of observation day $(\mathrm{d}=1, \ldots, \mathrm{K}), \mathrm{K}=43$ in summer and 58 in winter

$\mathrm{K}$ total number of observation days in summer and winter

$\mathrm{i} \quad$ index of data point in one day $(\mathrm{i}=1, \ldots, \mathrm{N}), N=144$

$\mathrm{N}$ total number of data points in one day

First, the differences of these factors were tested among all the five observation sites to prove the spatial variation in the study area. Second, we compared these microclimatic factors between shaded and unshaded sites (i.e., Site one and four) by subtracting the values from the shaded site from the unshaded site. This comparison indicates the level of microclimate regulation by the trees. Additionally, as the biophysical processes involved in microclimate regulation by trees are affected by the weather conditions (c.f. Wang et al. 2014), the trees' effect on microclimate should be evaluated under similar weather conditions. The influence of weather conditions on the trees' cooling effects was detemined afterwards. All of these effects should be bigger than the range of measurement accuracy (i.e., $\geq 0.5^{\circ} \mathrm{C} / 3 \%$ ).

\section{Clustering weather conditions}

In order to classify the weather conditions of the observation days, we utilized a clustering method, which included three features: clearness index (Kt), fluctuation of solar radiation (FR), and maximum Ta (MaxTa). After defining the cluster boundaries, $t$ both summer and winter observation days were clustered separately. 


\section{Clearness index $(\mathrm{Kt})$}

Kuye and Jagtap (1992) proposed a clearness index (ranging from 0 to 1) to characterize the sky conditions. Larger values represent clear weather, while low values represent cloudy weather. The index is calculated as the ratio of the global solar radiation measured at the surface and the clear sky solar radiation:

$$
K t_{d}=R_{d} / R 0_{d}
$$

With the global solar radiation $R$ based on the hourly average solar insolation (measured at weather station with 1 min sample interval). The clear sky solar radiation, $R 0$ is given by:

$$
R 0=\left(0.75+2 \times 10^{-5} z\right) R a
$$

The elevation $z$ of the weather station was $15 \mathrm{~m}$ above sea level (elevation of the study height plus height of the weather station). The extraterrestrial radiation $R a$ for each day was determined by the geographical position and the time of the year, according to:

$$
R a=\frac{T^{*} G^{*} d r}{\pi}[\omega \sin \varphi \sin \delta+\cos \varphi \cos \delta \sin \omega]
$$

Where $T$ is the length of day ( $24 \mathrm{~h}), G$ is the solar constant $\left(1353 \mathrm{~W} / \mathrm{m}^{2}\right), d r$ is the inverse relative distance Earth-Sun, $\omega$ is the sunset hour angle, $\varphi$ is the latitude and $\delta$ is the solar declination.

\section{Fluctuation of solar radiation (FR)}

Since the clearness index Kt only represents the daily value based on the hourly average solar insolation, it fails to capture the variation of solar intensity in the daily pattern. Therefore, we included the fluctuation rate (FR) of solar radiation to compute the variation of sunlight intensity for a given period. To determine the fluctuation rate of diurnal solar radiation (FR), we first de-trended the solar radiation time series $\left(R_{d i}\right)$ by subtracting the local trend value $\left(R_{d i}^{f i t}\right)$, and then calculated the root-mean-square of the cumulative difference between measurements and the local trend as:

$$
F R_{d}=\sqrt{\frac{1}{N} \sum_{i=1}^{N}\left(R_{d i}-R_{d i}^{f i t}\right)^{2}}
$$

To acquire the local trend value, a local regression using weighted linear least squares and a $2^{\text {nd }}$ degree polynomial model was applied to fit smooth curves with a four hours window span on a daily basis. Compared with the traditional moving average, this smoothing captures the major trends in the data but is less severely affected by the short-term fluctuation. FR is high when large changes in weather conditions occur, or when the weather varies during the day, and vice versa. As an example of a similar Kt but a very different FR, the diurnal $\mathrm{R}$ and detrended time series $\left(R_{d i}-R_{d i}^{f i t}\right)$ on $2^{\text {nd }}$ and $8^{\text {th }}$ August 2013 are presented in Fig. 3. Although the Kt's of these two days were nearly equal $(\approx 0.7)$, the FR's were very different. On $8^{\text {th }}$ August, the weather conditions varied strongly leading to a higher FR $\left(\mathrm{FR}=152 \mathrm{~W} / \mathrm{m}^{2}\right)$ compared to the $2^{\text {nd }}$ August that was a clear day $\left(\mathrm{FR}=16 \mathrm{~W} / \mathrm{m}^{2}\right)$. 


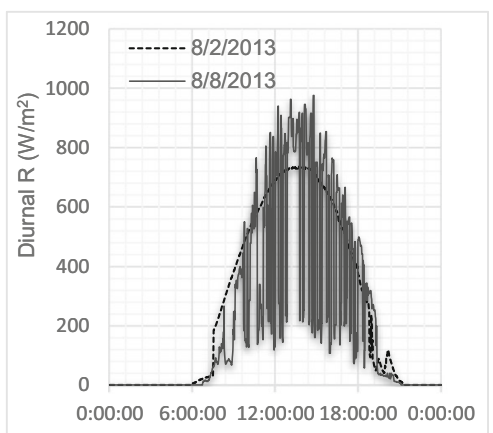

a

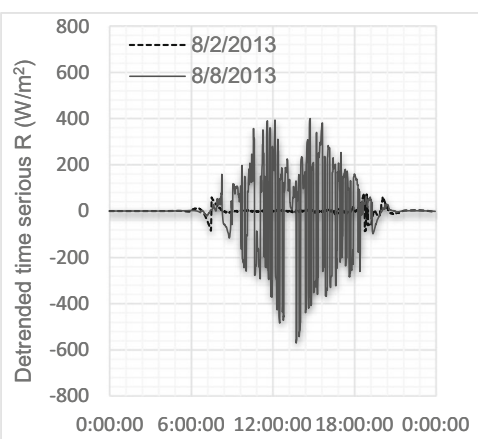

b

Fig. 3 Diurnal solar radiation time series R (a) and the de-trended time series (b) on 2nd and 8th August, 2013

\section{Maximum Ta (MaxTa)}

To investigate the effects of trees on extremely uncomfortable days, the maximum air temperature during the day (MaxTa) is also included as a feature for the clustering of the weather conditions. It highlights the hot days and relates to outdoor comfort level.

\section{Definition of clusters}

To define the clusters, FR and MaxTa were normalized to switch to the same scale as Kt, using:

$$
F(f)_{d}=\frac{f_{d}-\min _{d}\left(f_{d}\right)}{\max _{d}\left(f_{d}\right)-\min _{d}\left(f_{d}\right)}
$$

In this formula $\mathrm{f}$ stands for FR and MaxTa. The terms $\max (\mathrm{f})$ and $\min (\mathrm{f})$ are the maximum and minimum values among the observation days in the summer and winter respectively. We adopted a fast clustering method to classify the synoptic weather conditions using fixed cluster boundaries for all features. A value of 0.5 was set as cluster boundary for all the tree features included in this analysis. After the permutation and combination of the Kt, F(FR) and $\mathrm{F}(\mathrm{MaxTa})$, the observation days were classified into eight clusters. Note that the normalization process leads to cluster boundaries that depend on the dataset itself. Hence, if the changes of the weather conditions were negligibly small during the observation days, this clustering method may fail. Since the observation days should cover a variety of different weather conditions, a long-term observation period is essential for this method.

The definitions of each cluster were detailed below in Fig. 4a. Although all of the eight clusters characterize the different weathers, the analysis of this study focuses on cluster $\mathrm{C}$ and $\mathrm{F}$ since they stand for obvious different weather conditions. Cluster $\mathrm{F}$, having $\mathrm{Kt} \geq 0.5, \mathrm{~F}(\mathrm{FR})<$ $0.5, \mathrm{~F}(\mathrm{MaxTa}) \geq 0.5$, stands for the days having steady and strong solar radiation as well as a high maximum air temperature. Those days are relative clear and hot in summer and clear and mild in winter. In contrast, days with low fluctuations and intensity of solar radiation as well as a lower maximum air temperature (i.e., 'cloudy and cool' and 'cloudy and cold' weather condition) were classified as cluster $\mathrm{C}(\mathrm{Kt}<0.5, \mathrm{~F}(\mathrm{FR})<0.5, \mathrm{~F}(\mathrm{MaxTa})<0.5)$. 


\begin{tabular}{llll}
\hline Clusters & Kt & F(FR) & F(MaxTa) \\
A & $\geq 0.5$ & $\geq 0.5$ & $<0.5 ;$ \\
B & $\geq 0.5$ & $<0.5$ & $<0.5 ;$ \\
C & $<0.5$ & $<0.5$ & $<0.5 ;$ \\
D & $<0.5$ & $\geq 0.5$ & $<0.5 ;$ \\
E & $\geq 0.5$ & $\geq 0.5$ & $\geq 0.5 ;$ \\
F & $\geq 0.5$ & $<0.5$ & $\geq 0.5 ;$ \\
G & $<0.5$ & $<0.5$ & $\geq 0.5 ;$ \\
H & $<0.5$ & $\geq 0.5$ & $\geq 0.5 ;$ \\
\hline
\end{tabular}

a

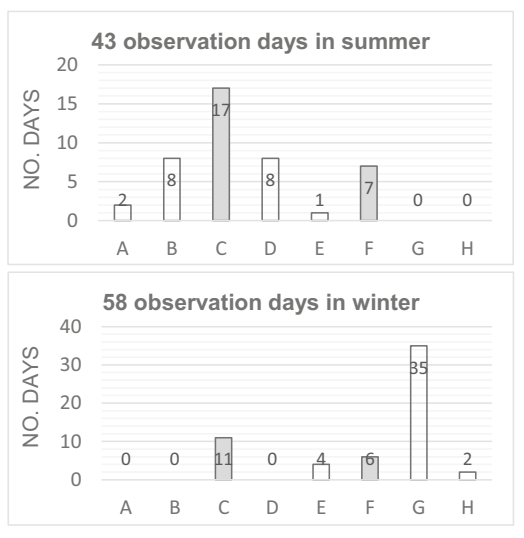

b

Fig. 4 The definitions of clusters of the synoptic weather conditions (a) and clustering results for the summer and winter observation days (b)

\section{Clustering results}

Figure $4 \mathrm{~b}$ represents the clustering results for both summer and winter observation days. In the summer, 43 observation days fell under six clusters (A-F). Most of these days (40\%) were relatively cloudy and cool (cluster $\mathrm{C}$ ), whereas only 7 days (16\%) were relatively clear and hot (cluster F). Among the 58 observation days in the winter, most days (80\%) were cloudy (cluster $\mathrm{C}$ and $\mathrm{G}$ ), indicated by a low $\mathrm{Kt}(<0.5)$ and $\mathrm{F}(\mathrm{FR})(<0.5)$. However, only 11 days $(19 \%)$ had a low F(MaxTa) $(<0.5)$ and fell under cluster C. Additionally, clear and mild weather conditions (cluster F) were found in 6 days $(10 \%)$.

The features mentioned in Section 2.2.2 were computed and compared among different clusters. Furthermore, representative days were selected from the 'cloudy and cool' and 'cloudy and cold' clusters $\mathrm{C}$ and 'clear and hot' and 'clear and mild' clusters $\mathrm{F}$ for the model simulation.

\section{Numerical modelling}

Three-dimensional numerical microclimate simulations using ENVI-met were conducted to explore the relation between tree characteristics and temperature and humidity distribution in the study area. Based on the fundamental laws of fluid dynamics and thermodynamics, ENVImet is designed to simulate surface-plant-air interactions in an urban environment (Bruse 2010) and has been used in different studies (Emmanuel et al. 2007; Fahmy et al. 2009; Hedquist and Brazel 2014; Middel et al. 2014). ENVI-met allows to simulate the urban environment from a microclimate scale to the local climate scale with a resolution of 0.5 to $10 \mathrm{~m}$ in space and $10 \mathrm{~s}$ in time with 250 grids at maximum. In this study, the geometry, buildings, vegetation, and surface materials of the study area are defined on a 3D grid of $120 \times$ $120 \times 30$ cells, with a $0.5 \mathrm{~m}$ grid cell size. This resolution allows to investigate local microclimate variations (Bruse 2010). The geometry, plant and soil database, and building properties specified for this study were based on data from the Top10NL map ${ }^{2}$ and measurements. For

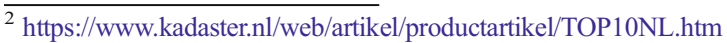


the plant database, ENVI-met requires the vertical distribution of leaf area density in ten different heights. We first determined the vegetation leaf index (LAI) of the trees within model area with a LAI-2000 Plant Canopy Analyser under cloudy weather condition. Subsequently, leaf area density values in ten different heights were calculated using the method by Lalic and Mihailovic (2004). In addition, the field measurements were used as the input data for model initialization. These include wind velocity, wind direction, initial air temperature, relative and specific humidity, and indoor temperature.

In addition, ENVI-met allows to select the points inside the model area where the processes in the atmosphere and the soil are calculated in more detail. These selected points are named 'receptors'. In order to capture this detailed information within the study area, 81 equidistant receptors were added in the area input file (labelled AA-II in Fig. 5). However, the 13 receptors that were located on the façade of buildings, did not monitor the outdoor processes and were eliminated from the statistical analysis. After running a $24 \mathrm{~h}$ simulation with a half hour interval the following features were extracted from the receptors at $1.5 \mathrm{~m}$ height: Ta and $\mathrm{RH}$, wind velocity (Va), longwave and shortwave radiation, and the Predicted Mean Vote (PMV). The PMV methodology determines thermal comfort (ISO 7726 1998), ranging from $3=$ 'very cold' to $+3=$ 'very hot') (Matzarakis and Mayer 1998); and is calculated by combining $\mathrm{Ta}, \mathrm{RH}$ and $\mathrm{Va}$ with parameters that describe the heat exchange processes of the human body. To calculate PMV in ENVI-met, we set biometeorological values for people's slow walk to $1.4 \mathrm{~m} / \mathrm{s}$ and a $150 \mathrm{~W} / \mathrm{m}^{2}$ energy exchange. Thermal resistance of clothing was adjusted depending on summer and winter clothing.

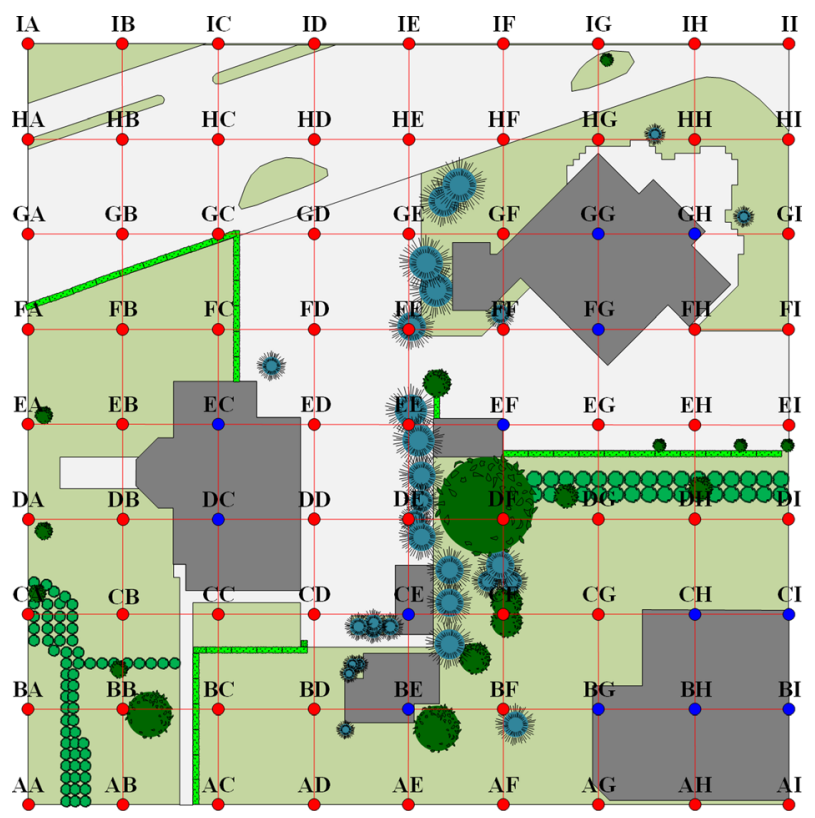

Fig. 5 ENVI-met map of the study area where 81 equidistant receptors are indicated with a grid identifier ranging from AA to II. The blue circles represent 13 receptors located on the façade of buildings; while the red circles indicate the rest receptors 


\section{Selection of comparable days and model validation}

Using the clustering results, four days in the summer and winter were selected at random from cluster $\mathrm{C}$ and $\mathrm{F}$ (i.e., $2^{\text {nd }}, 3^{\text {rd }}$ August, 2013 and $18^{\text {th }}, 21^{\text {st }}$ January, 2014). The weather conditions of these selected days are shown in Table 1 . On the clear days (e.g., $2^{\text {nd }}$ August and $18^{\text {th }}$ January), the daily total solar radiation was much higher than on cloudy days. The wind velocity was less than 3 Beaufort $(<11 \mathrm{~km} / \mathrm{h})$ during these four days. The dominant wind direction was SE on both 'clear and hot' summer day and 'clear and mild' winter day, but SW on the 'cloudy and cool' summer day and 'cloudy and cold' winter day.

An evaluation of the accuracy of predicted ENVI-met $(\mathrm{P})$ values with observed temperature at five sites was performed among these four selected days. Figure 6 shows the results from Sites one and four on August $2^{\text {nd }}$ as an example. A notable contrast between the observed and simulated Ta can be observed. As expected, the maximum Ta within the tree canopy (Site four) was approximately $1{ }^{\circ} \mathrm{C}$ lower than that of the area without trees. However, the simulation and measurement results show two discrepancies. First, the simulation results tend to underestimate daytime temperatures and overestimate night-time temperatures. Second, the poorer model performance appeared in the afternoon when temperature and humidity strongly swung. ENVI-met failed to simulate these rapid microclimatic changes. One of ENVI-met's limitations is that its simulation output is time and space (within one grid) averaged (Emmanuel et al. 2007; Peng and Jim 2013). Therefore, the diurnal temperature variations are contracted. Furthermore, the simulated data cannot represent instant temperature conditions because such models always keep a constant tendency (Peng and Jim 2013). The possible immediate disturbances, which are observed from measurements, cannot be realistically reflected in the model outputs. This leads to the underestimation of the reduction of the temperature and its fluctuations caused by trees.

Despite this deficiency, the simulated Ta showed good qualitative agreement with the measurements based on both correlation coefficient $\left(\mathrm{R}^{2}\right)$ and error indices (root mean square error-RMSE and mean absolute error-MAE). Lower RMSE and MAE values indicate a better model performance. The index of agreement (d), which was developed by Willmott (1981), measures the degree of model prediction error and ranges from 0 to 1 . A higher value indicates a better agreement between simulation and measurement. $\mathrm{R}^{2}$ among the five sites ranged between 0.73 and 0.97 on the selected two summer days, and between 0.79 and 0.95 on the selected two winter days. RMSE and MAE were low throughout all sites and d was generally> 0.60 . Table 2 shows the evaluation results for each site in detail on the four selected days.

Table 1 Weather conditions of selected days

\begin{tabular}{lllllll}
\hline Days & Cluster & $\begin{array}{l}\text { Weather } \\
\text { condition }\end{array}$ & $\begin{array}{l}\text { Daily total solar } \\
\text { radiation }\left(\mathrm{W} / \mathrm{m}^{2}\right)\end{array}$ & $\begin{array}{l}\text { Relative } \\
\text { humidity }(\%)\end{array}$ & $\begin{array}{l}\text { Wind velocity } \\
(\mathrm{km} / \mathrm{h})\end{array}$ & $\begin{array}{l}\text { Dominant wind } \\
\text { direction }\end{array}$ \\
\hline $\begin{array}{l}\text { Summer } \\
\text { 2nd, Aug, 2013 }\end{array}$ & F & Clear & 6378.82 & $69 \%$ & 6.8 & SSE \\
3rd, Aug, 2013 & C & Cloudy & 4906.10 & $71 \%$ & 10.7 & WSW \\
$\begin{array}{l}\text { Winter } \\
\text { 18th, Jan, 2014 }\end{array}$ & F & Clear & 614.03 & $92 \%$ & 5.1 & ESE \\
21st, Jan, 2014 & C & Cloudy & 101.73 & $96 \%$ & 3.2 & WSW \\
\hline
\end{tabular}



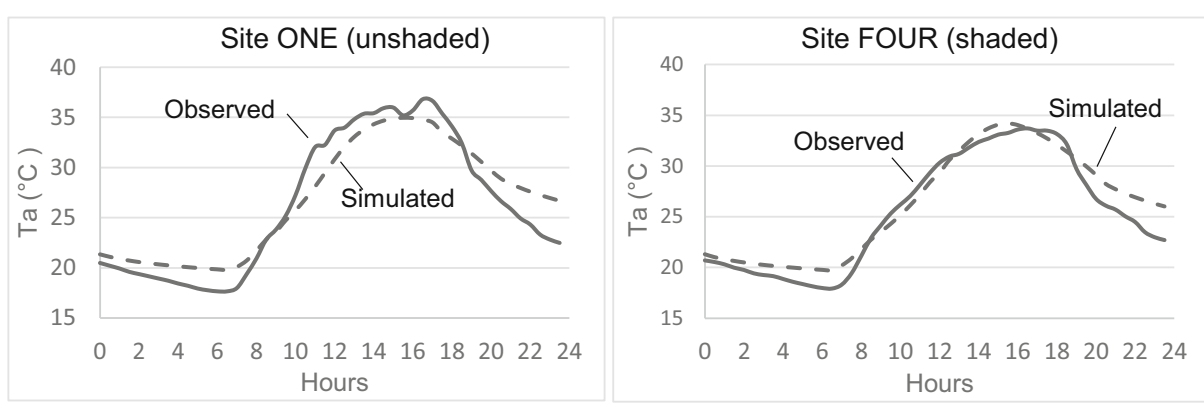

a

b

Fig. 6 Measured and simulated temperature values at an unshaded site (a) and shaded site (b) on the $2^{\text {nd }}$ August, 2013

Table $2 \mathrm{R}^{2}$, RMSE, RSR, MAE and d between the measured and the computed air temperatures in $24 \mathrm{~h}$ period

\begin{tabular}{lllll}
\hline Days & $\begin{array}{l}\text { Correlation } \\
\text { coefficient } \mathrm{R}^{2}\end{array}$ & $\begin{array}{l}\text { Root mean square } \\
\text { error } \operatorname{RMSE}\left({ }^{\circ} \mathrm{C}\right)\end{array}$ & $\begin{array}{l}\text { Mean absolute } \\
\text { error } \operatorname{MAE}\left({ }^{\circ} \mathrm{C}\right)\end{array}$ & $\begin{array}{l}\text { Index of } \\
\text { agreement } d\end{array}$ \\
\hline
\end{tabular}

Summer

2nd, Aug, 2013

Site one

0.97

0.66

0.41

0.97

Site two

0.96

0.14

0.89

0.99

Site three

0.95

0.65

0.35

0.98

Site four

0.98

0.90

0.76

0.96

Site five

0.95

0.76

0.56

0.97

21st, Jan, 2014

Site one

0.92

1.47

1.13

0.73

Site two

0.81

1.66

1.18

0.70

Site three

0.82

2.13

1.71

0.73

Site four

0.81

1.65

1.41

0.68

Site five

0.73

1.97

1.62

0.63

Winter

18th, Jan, 2014

Site one

0.70

0.60

0.87

Site two

0.91

0.86

0.79

0.80

Site three

0.91

0.63

0.45

0.89

Site four

0.91

0.61

0.42

0.88

Site five

0.95

0.64

0.43

0.87

21st, Jan, 2014

Site one

0.81

0.28

0.25

0.85

Site two

0.79

0.28

0.24

0.85

Site three

0.87

0.64

0.63

0.64

Site four

0.86

0.54

0.51

0.70

Site five

0.85

0.31

0.27

0.81 


\section{Simulation design and data analysis}

In order to examine the effects of the trees at the study site on the microclimate and thermal comfort, we compared the simulations of the current situation (CU) (i.e., with $5 \%$ total tree cover and $3 \%$ evergreen tree cover in the summer and winter, respectively) and no tree (NT) conditions on selected days. In the NT simulation, we removed all the trees, including both deciduous and evergreen trees, from the model area.

First, we investigated how trees affect the microclimate over the entire area. Based on the $24 \mathrm{~h}$ simulations for all 68 receptors, the maximum, minimum and average CR and Range for air temperature were calculated. The mean of these features for all the receptors was derived separately on the four selected days as expressed in Eq. 7.

$$
\text { Mean of receptors }=\frac{1}{M} \sum_{j=1}^{M}\left(D F c u_{j}-D F n t_{j}\right)
$$

In this formula, $\mathrm{M}$ is the number of the receptors and $\mathrm{j}$ is the index of receptors. DFcu and DFnt are the daily values of different features in the CU and NT simulations, respectively. We calculated the difference between DFcu and DFnt, and then derived the average value for all the receptors.

Second, we investigated if the spatial temperature distribution changes over time. The Ta differences $\left(\Delta \mathrm{Ta}_{\mathrm{ji}}\right)$ between $\mathrm{CU}$ and NT simulations were calculated at each receptor $j$ and each time step $i$. To quantify the spatial differences of the effects of the trees, the time-series range of $\Delta$ Ta among the receptors is defined in Eq. 8.

$$
(\text { Range of } \Delta T a)_{i}=\max _{j}\left(\Delta T a_{j i}\right)-\min _{j}\left(\Delta T a_{j i}\right)
$$

Where the terms of $\max _{j}\left(\Delta T a_{j i}\right)$ and $\min _{j}\left(\Delta T a_{j i}\right)$ are the maximum and minimum Ta of 68 receptors at time $\mathrm{i}$. Time and place in which the temperature was greatly influenced by the trees is determined in this way.

Due to the effects on the microclimate, trees altered the outdoor human comfort level as well, especially during the hottest hours of the day (from 12:00 to 18:00). After extracting the PMV value during the hottest hours from ENVI-met, we calculated the occurrence frequency of the PMV value at different scales under CU and NT conditions. The comparison between CU and NT conditions helped us to analyse how the trees determine the outdoor human comfort.

\section{Results}

\section{Measurement results}

\section{Effect of trees on microclimate in the summer}

Microclimatic differences among the observation sites During daytime in the summer period, a significant difference in $\mathrm{CR}$ and Range of Ta/RH among the observations sites was revealed by one-way MANOVA $(p<.0005)$. In terms of the air temperature, the observation location has a statistically significant effect on both CR $(p=.033)$ and Range $(p<.0005)$. The results from the multiple comparisons showed that $\mathrm{CR}$ and Range of Site one were significantly 
different from that of the other sites ( $p<.05$ for both CR and Range). Similar results were also found for RH. Generally speaking, the variation rates and ranges of air temperature and humidity varied significantly among the observation sites. Although the maximum, minimum and average $\mathrm{Ta} / \mathrm{RH}$ did not show significant differences for the observation sites, the differences between these features and their mean values of all sites, i.e., $\mathrm{D}(\mathrm{t})$, were significant $(p<.0005$ for all). Hence, we conclude that, during the daytime of the summer period, the microclimatic conditions at the observation sites had significant differences. In terms of the microclimate at night, the spatial differences of temperature and humidity were significant among the sites, with $\mathrm{D}(\mathrm{t})$ of $\mathrm{Ta} / \mathrm{RH}$ varied significantly among the different sites $(p<.0005$ for all).).

Microclimatic differences between shaded and unshaded areas According to the statistical tests, tree canopy significantly reduced CR by approximately 0.04 (standard deviation $(\mathrm{SD})=0.03)$ and the Range of Ta by $2.4^{\circ} \mathrm{C}\left(\mathrm{SD}=0.9^{\circ} \mathrm{C}\right)$ in the daytime. This means that trees efficiently reduce the daily temperature difference and variation during the hot months. Moreover, the shade of trees reduced the air temperature significantly during daytime with $\mathrm{D}(\mathrm{t})$ $(p<.05$ for all). Fig. 7 illustrates the differences in average and maximum Ta between the shaded and unshaded area during this period. This difference was computed by subtracting Ta measured in shaded areas from that of unshaded areas. The average Ta and $\mathrm{RH}$ in tree covered areas was $1{ }^{\circ} \mathrm{C}\left(\mathrm{SD}=0.4{ }^{\circ} \mathrm{C}\right)$ lower and $3 \%(\mathrm{SD}=1.2 \%)$ higher than those of unshaded areas. However, the differences of maximum Ta and minimum $\mathrm{RH}$ were enlarged to $2.5^{\circ} \mathrm{C}(\mathrm{SD}=$ $\left.0.9^{\circ} \mathrm{C}\right)$ and $5 \%(\mathrm{SD}=2.3 \%)$, while they could reach a maximum of $4.1{ }^{\circ} \mathrm{C}$ and $10 \%$ at noon. At night, the tree covered area has a slightly lower Range of Ta (approximately $0.1^{\circ} \mathrm{C}$ ). This difference was also observed on the calm or light air days with relatively little heat convection.

Weather effects in the daytime To investigate the weather effects on the microclimatic condition, the comparison of Ta and $\mathrm{RH}$ between relatively cloudy and cool days (cluster $\mathrm{C}$ ) and clear and hot days (cluster F) during the daytime was made, highlighted by respectively circles and triangles in Fig. 7. The results revealed that on the cloudy and cool days, both CR and the Range of $\mathrm{Ta} / \mathrm{RH}$ was not significantly different among the sites ( $p>.05$ for all). However, these features differ significantly for the different sites on the clear and hot days $(p<.0005$ for all). In addition, the differences of $\mathrm{D}(\mathrm{t})$ for $\mathrm{Ta} / \mathrm{RH}$ among the different sites were significant on both cloudy and cool days and clear and hot days, with $p<.0005$ for all the

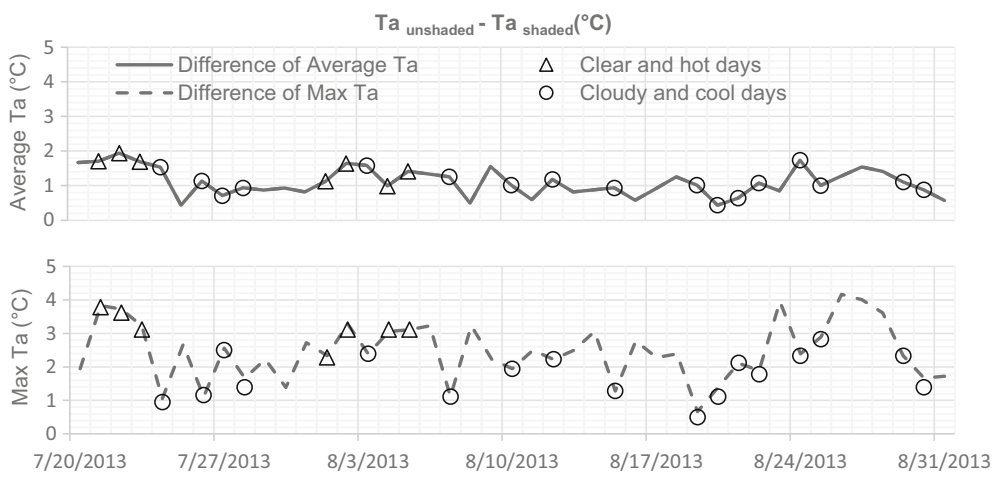

Fig. 7 Difference in average and maximum Ta between the shaded and unshaded site of the trees in the summer daytime (from 06:00 to 21:00) 


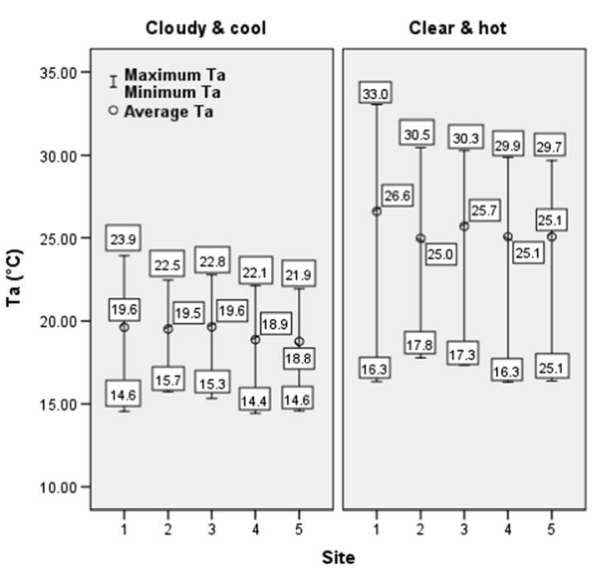

a

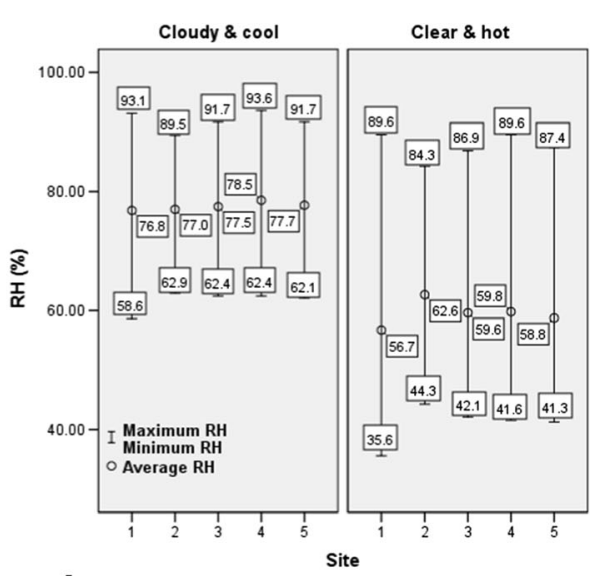

b

Fig. 8 Comparison of maximum, minimum and average Ta (a) and RH (b) at five sites between cloudy and cool and clear and hot days

features. Figure 8 shows the maximum, minimum and average Ta and RH for each observation site, on average during both cloudy and cool and clear and hot days.

We compared the maximum, minimum and average Ta and RH in the shaded area with those ones in the unshaded area. On relatively cloudy and cool days, the maximum and average $\mathrm{Ta}$ within the tree canopy were approximately $1.8^{\circ} \mathrm{C}\left(\mathrm{SD}=0.7^{\circ} \mathrm{C}\right)$ and $0.8^{\circ} \mathrm{C}\left(\mathrm{SD}=0.2^{\circ} \mathrm{C}\right)$ lower than those of the unshaded area. These temperature differences were enlarged to $3.2^{\circ} \mathrm{C}(\mathrm{SD}=$ $\left.0.5^{\circ} \mathrm{C}\right)$ and $1.5^{\circ} \mathrm{C}\left(\mathrm{SD}=0.2{ }^{\circ} \mathrm{C}\right)$ on relatively clear days. The average $\mathrm{RH}$ of shaded areas exceeds that of unshaded areas by $3 \%(\mathrm{SD}=0.8 \%)$ on cluster $\mathrm{C}$ days, and $3 \%(\mathrm{SD}=1.4 \%)$ on cluster $\mathrm{F}$ days. In general, on relatively clear and hot days, the Ta reduction by the trees was about two times higher than that on the cloudy and cold days. A table summarizing daytime Ta and RH between cloudy and cool and clear and hot days is shown in Appendix 1.

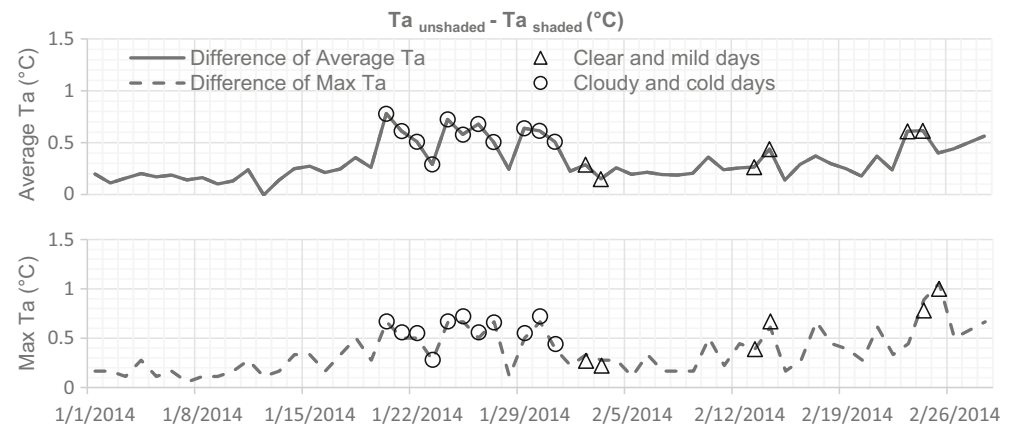

Fig. 9 Difference in average and maximum Ta between the shaded and unshaded sites in the winter daytime (from 06:00 to 21:00) 


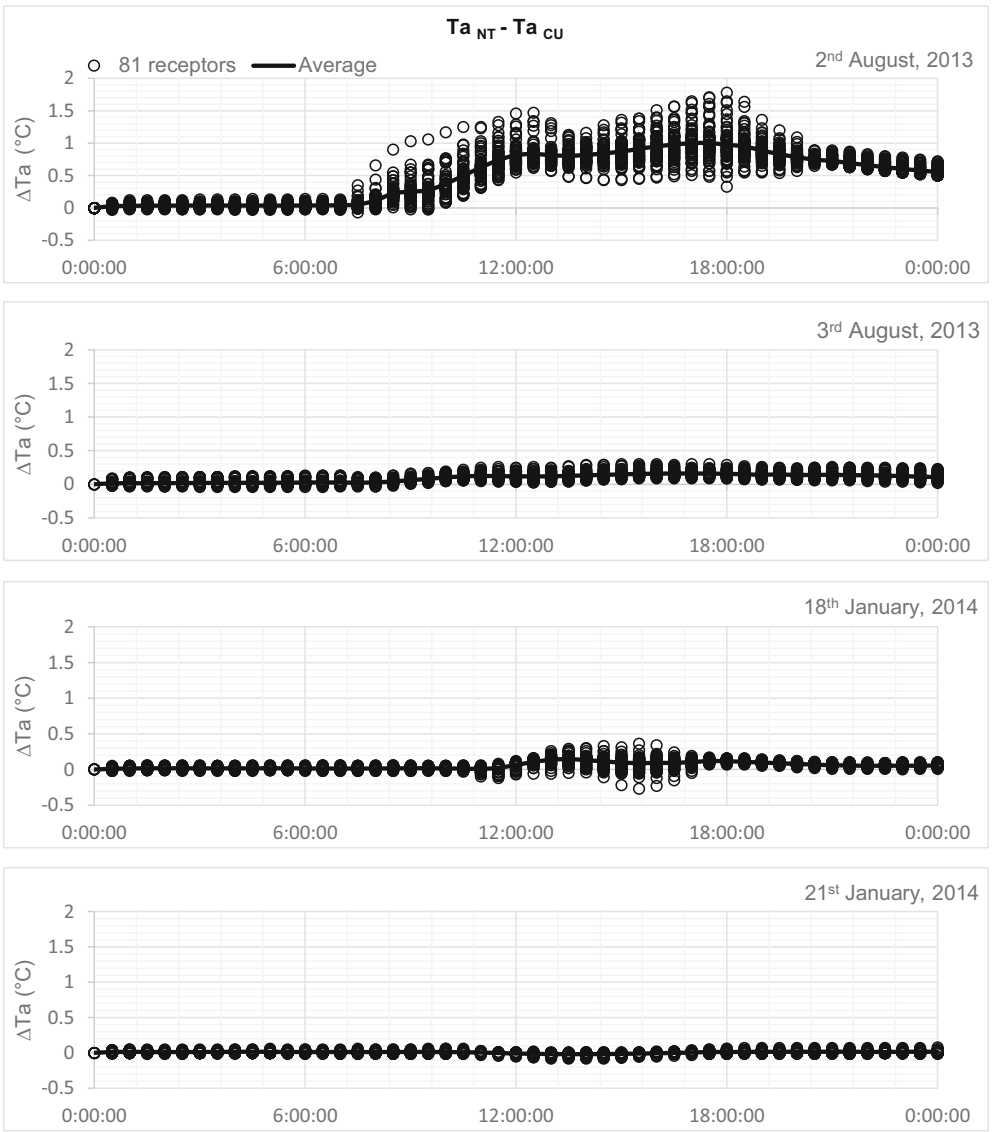

Fig. 10 The differences of $\Delta \mathrm{Ta}$ under $\mathrm{CU}$ and NT conditions among 68 receptors on selected days

Effect of trees on microclimate in the winter

Microclimatic differences among the observation sites Although the effects of trees did not lead to significant differences in CR and Range for Ta/ $\mathrm{RH}$ ( $p>.05$ for all) during both daytime and night time, the distribution of air temperature and humidity was significantly

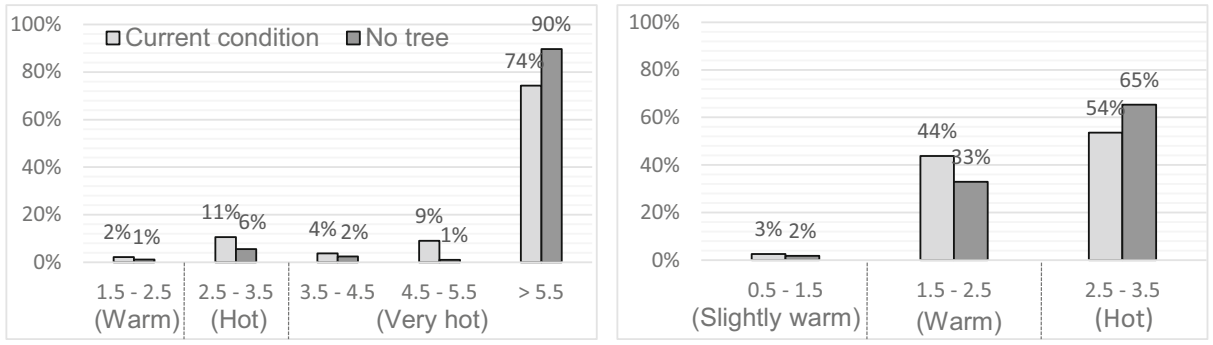

Fig. 11 Frequency of PMV value at different scales from 12:00 to 18:00 on clear and hot day (a) and cloudy and cool day (b) 
different $(p<.0005$ for all the $\mathrm{D}(\mathrm{t})$ of $\mathrm{Ta} / \mathrm{RH}$ in both daytime and night time) among the observation sites.

Microclimatic differences between shaded and unshaded area The positive cooling effect of $3 \%$ by evergreen trees in the study area in the summer may lead to disservices in the winter. In the daytime there was no significant difference in CR and Range of Ta/RH between shaded and unshaded area but we found that the trees significantly lowered the average Ta and raised the average $\mathrm{RH}$ by respectively $0.5{ }^{\circ} \mathrm{C}\left(\mathrm{SD}=0.2{ }^{\circ} \mathrm{C}\right)$ and $3 \%(\mathrm{SD}=0.6 \%)$. The maximum differences of maximum Ta and minimum $\mathrm{RH}$ were up to $1{ }^{\circ} \mathrm{C}$ and $5 \%$ at noon (Fig. 9). The decreased air temperature may lead to an increase of heating energy consumption and a decline of outdoor thermal comfort.

Theoretically, at night, tree canopy prevents the heat flow from the surface to the surroundings and slows down heat losses, thus increasing the Ta and lowering the CR and Range of Ta. However, the measured effect of the evergreen trees on the microclimate at night was not significant, with $p>.05$ for both the trends and values of Ta. Wind velocity was a significant factor in explaining the Ta range differences between the shaded and unshaded area, with $p=$ 0.042 . On calm or light air days, the Ta range was slightly lowered by the trees.

Weather effects in the daytime In terms of the weather effects during the daytime in winter, the statistical tests indicated that no significant differences on either measured value or trend for both Ta and RH between cloudy and cold and clear and mild days ( $p>.05$ for all) were found (see also the marked days by the circles and triangles in Fig. 9). Accordingly, we concluded that the weather conditions in the winter did not cause a notable change on performance of trees on the microclimate. Appendix 2 summarizes the daytime maximum, minimum and average Ta and RH under the cloudy and cold and clear and mild weather conditions.

\section{Modelling results}

\section{Effect of trees on outdoor microclimate}

Appendix 3 shows the maximum, minimum and average air temperature for both current (CU) and no-tree (NT) conditions on selected days in detail. To better understand the impact of the trees on the microclimatic condition, we calculated the Ta difference $(\Delta \mathrm{Ta})$ caused by the absence of trees (i.e., Ta in CU condition was subtracted from Ta in NT condition at each receptor and each time step for four selected days). Fig. 10 represents the $\Delta$ Ta between CU and NT for all the receptors in $24 \mathrm{~h}$.

Spatial variation on the summer days On a selected clear and hot day ( $2^{\text {nd }}$ August 2013), $5 \%$ tree cover reduced maximum Ta with $1.1^{\circ} \mathrm{C}\left(\mathrm{SD}=0.23{ }^{\circ} \mathrm{C}\right)$. At Site four with trees, the maximum Ta differed by as much as $1.4^{\circ} \mathrm{C}$ for simulated situations with and without trees. In addition, trees reduced the daily Range of Ta by approximately $1{ }^{\circ} \mathrm{C}\left(\mathrm{SD}=0.24{ }^{\circ} \mathrm{C}\right)$. Unlike the remarkable differences in the Range, the differences of CR between CU and NT conditions were small. Appendix 4 shows the daily average value, CR and Range for Ta in both CU and NT conditions on a clear and hot day. On the selected cloudy and cool day (3rd August 2013), the influence of trees on Ta was much smaller, with only $0.3{ }^{\circ} \mathrm{C}\left(\mathrm{SD}=0.05{ }^{\circ} \mathrm{C}\right)$ maximum $\mathrm{Ta}$ reduction at Site four. The reduction of CR and Range was small. 
Although the simulated results cannot reflect the large fluctuation in air temperature and humidity at a specific location (see 3.2.1), the differences in the effect of trees among the receptors were notable. On the clear and hot day, the range of $\Delta \mathrm{Ta}$ between the area with the strongest effect and the area with the weakest effect was about $0.6{ }^{\circ} \mathrm{C}\left(\mathrm{SD}=0.41{ }^{\circ} \mathrm{C}\right)$ on average. This range went up to $1.5^{\circ} \mathrm{C}$ at the time of the peak reduction at 18:00 (Fig. 10). The spatial variation on the cloudy and cool day was much smaller than that on the clear and hot day. The daily average range of $\Delta \mathrm{Ta}$ was about $0.2{ }^{\circ} \mathrm{C}\left(\mathrm{SD}=0.03{ }^{\circ} \mathrm{C}\right)$, and went up to $0.3{ }^{\circ} \mathrm{C}$ at $13: 30$.

Spatial variation on the winter days According to the simulation results, the reductions of maximum Ta were estimated to be $0.2^{\circ} \mathrm{C}\left(\mathrm{SD}=0.05^{\circ} \mathrm{C}\right)$ and less than $0.1{ }^{\circ} \mathrm{C}\left(\mathrm{SD}=0.02{ }^{\circ} \mathrm{C}\right)$, on the clear and mild day and the cloudy and cold day (i.e., $18^{\text {th }}$ and $21^{\text {st }}$ January 2014), respectively. During the afternoon of these two winter days, the temperature in areas with trees was slightly higher than in area without trees. This was reflected by the negative values of $\Delta \mathrm{Ta}$ in Fig. 10, which could increase human thermal comfort. The effect of these trees on the CR and Range of Ta was negligiblely small.

Among the receptors from the locations far from to close to the trees, the daily average range of $\Delta \mathrm{Ta}$ was about $0.2{ }^{\circ} \mathrm{C}\left(\mathrm{SD}=0.14^{\circ} \mathrm{C}\right)$ on clear and mild days. The variation of $\Delta \mathrm{Ta}$ among the receptors reached a peak at $15: 30$, with $0.5^{\circ} \mathrm{C}$ difference between the areas with the strongest and weakest effect (Fig. 10). On the cloudy and cold winter day, the effect of trees on the temperature distribution was small. Hence, the spatial differences of $\Delta$ Ta tended to be small as well (i.e., less than $0.1^{\circ} \mathrm{C}$ on average).

\section{Effect of trees on outdoor thermal comfort}

Predicted mean vote on the summer days To better understand how trees affect outdoor thermal comfort during the hottest hours in the summer, the PMV value during 12:00-18:00 at each receptor was derived from the model results under CU and NT conditions respectively. Figure 11 shows the occurrence frequency of the PMV value at different scales from 12:00 to 18:00 on both clear and hot days and cloudy and cool days.

On the clear and hot day, tree shading during the hottest hours significantly influenced human comfort simulation results. Comparison of the average PMV indicates that in this period trees could reduce the high PMV of $>5.5^{\circ} \mathrm{C}$ by $16 \%$ while increasing the low PMV of $1.5-2.5^{\circ} \mathrm{C}$ by $1 \%$ and $2.5-3.5^{\circ} \mathrm{C}$ by $5 \%$. Although the comfort level in most areas was still uncomfortable it is better than the 'very hot' thermal perception experienced for the same time period at all other places within model area. Under the tree canopy, the PMV value was decreased by $2.7^{\circ} \mathrm{C}$. During the hottest hours of the cloudy and cool day, the 'hot' thermal perception $\left(2.5-3.5^{\circ} \mathrm{C}\right)$ was reduced by $11 \%$. The moderation of temperature at night by trees led to different effects on human comfort depending on the weather conditions. However, these impacts were small with thermal perceptions ranging from 'comfortable' to 'warm'. Appendix 5 and Appendix 6 display the comfort level under CU and NT condition at 14:00 and 22:00 of the selected days.

PMV value on the winter days During the two selected days in the winter, the comfort was highest in the afternoon hours. On the clear and mild day, PMV values, though slightly lower in the shade, were estimated to be at 'comfort' and 'slightly warm' levels over the entire area (Appendix 5). In theory, evergreen trees could improve human comfort at night by retarding 
heat losses and reducing the cold wind blowing and block the heat loss. However, the changes on the comfort level were negligible small on both selected days (Appendix 6).

\section{Discussion}

\section{Measurement results}

\section{Microclimatic differences}

The measurement results confirmed that tree covered areas show lower average air temperature during the daytime in the summer than the unshaded area by approximately $1{ }^{\circ} \mathrm{C}$. This agrees with previous studies that reported a $0.9-2{ }^{\circ} \mathrm{C}$ reduction of average ambient air temperature in areas with vegetative canopy (McPherson et al. 1989; Taha et al. 1991; Park et al. 2012). Additionally, previous studies proved that evergreen trees also reduce the temperature in the winter (Akbari 2002; Mcpherson 1988). This was also observed in our measurements.

Theoretically, evergreen trees can prevent the vertical heat transfer and reduce the heat exchange between areas below and above the canopy at night in the winter (Akbari 2002; Heisler and Grant 2000; Mcpherson 1988), thereby increasing the Ta and lowering the CR and Range of Ta. However, this has not been observed from our measurements. A plausible explaination is that the heat convection in the winter was strong. This affected the temperature spatial distributation, since the wind velocity was a significant factor in explaining the differences of Range of Ta between the shaded and unshaded area.

\section{Weather effects}

In our study we used a cluster methodology to characterise the sky conditions, integrating the clearness index, the variation of solar intensity and the maximum air temperature. Cooling effects of trees on relatively clear and hot days were about two times higher than on the cloudy and cold days. Similar results were also reported by another study that investigated the thermal conditions of the typical shaded and un-shaded buildings in the summer and dry season (December-February) in Nigeria (Morakinyo et al. 2013). They analyzed the variation of outdoor air temperature in relation to different weather conditions. A clearness index was used to characterize weather conditions. Their results confirmed that the influence of trees on the outdoor air temperature became less with the increase of cloudiness.

Our findings also indicate that, during the daytime in the winter, different weather conditions did not cause a notable change of tree effects on microclimate. That is most likely due to the fact that the variation of incoming solar radiation under the different weather conditions was rather small because of the low solar intensity.

\section{Modelling results}

Numerical models such as ENVI-met probably introduce a bias in the simulations. The model results poorly represent instant temperatures and fail to capture the real instantaneous changes of air temperature and humidity. This inability of ENVI-met has been reported by several 
studies (e.g., Emmanuel et al. 2007; Peng and Jim 2013). The good simulations' agreement with the measurements, however, indicated that our input parameters were adequate for the local scale simulations.

\section{Spatial variation}

In the summer, the spatial differences of $\Delta \mathrm{Ta}$ among the receptors in the model were found to vary strongly, being $1.5{ }^{\circ} \mathrm{C}$ and $0.2^{\circ} \mathrm{C}$ at maximum values on clear and cloudy days respectively. In the winter, the maximum spatial differences were smaller but still apparent with $0.5^{\circ} \mathrm{C}$ and $0.1{ }^{\circ} \mathrm{C}$ on clear and cloudy days. This demonstrates that, when the weather is clear and hot, trees efficiently alter the local microclimate and cause large variations in close geographical proximity. To better understand the effects of trees on the local urban microclimate and to identify and quantify the effect of urban trees on local outdoor microclimate and human thermal comfort, essential empirical information on the microclimate must be collected in close geographical proximity.

\section{Thermal comfort}

We extracted the simulated PMV value from ENVI-met to illustrate the thermal perception in the study area. The maximum PMV (i.e., extra uncomfortable thermal perception) was notably reduced during the hottest hours on both clear and cloudy days. Fahmy et al. (2009) stated that PMV differs depending on density of the trees. Further study in this direction is necessary to compare the cooling effects among the trees with different density and height. Although PMV was developed based on a huge database, human comfort levels highly depends on the human thermal perception, expectation and preference in the particular study context (area and time). Hence, field surveys are necessary to investigate the subjective responses for people thermal sensations in the local area.

\section{Conclusion}

This study provides new insight into the role of trees on microclimate and human thermal comfort in a local urban area through field measurements and modelling. The effect of weather conditions on the cooling performance of trees was analysed. Observed weather conditions were clustered to investigate the differences in cooling effect of trees and to select the appropriate days for the simulations.

The results from both the measurements and the simulations showed that trees significantly altered the surrounding summer microclimate. The comparison on the measurements between the shaded and unshaded area showed that the daily maximum air temperature differed by $2.5^{\circ} \mathrm{C}$. Significant spatial variations were caused by the trees. Trees considerably improved the thermal comfort level through reducing the 'very hot' and 'hot' thermal conditions in the study area. Additionally, we found that the evergreen trees also lowered the average winter air temperature by $0.5^{\circ} \mathrm{C}$. The benefit of this effect, can potentially be offset through increased energy costs.

The biophysical processes involved in microclimate regulation by trees are affected by, among others, the surrounding temperature, humidity and solar radiation, whereby the cooling effect of trees was greatly influenced by prevailing weather conditions. The measurements in 
the shaded and unshaded areas revealed that, on relatively clear and hot days, the Ta reduction by the trees was about two times higher than that on cloudy and cold days. Also the simulations with ENVI-met showed strongly varying temperature conditions spatially. Hence, when studying the influence of trees on the microclimate, weather conditions must be considered, especially in the summer. We conclude that trees, as an important element in urban green infrastructure, are very effective in regulating the microclimate and enhancing thermal comfort locally. Weather conditions, however, strongly influence the trees' performance in such microclimate regulation, especially in the summer.

Funding This study was funded by INCAS3.

Conflict of interest The authors declare that they have no conflict of interest.

\section{Appendix 1 Summarize table on daytime Ta and RH between cloudy and cool and clear and hot days in the daytime of summer}

\begin{tabular}{|c|c|c|c|c|c|c|}
\hline \multirow[t]{3}{*}{ Weather } & \multirow[t]{3}{*}{ No. of days } & \multirow[t]{3}{*}{ Features } & \multicolumn{2}{|c|}{ Features on daily basis ${ }^{\mathrm{a}}$} & \multirow{2}{*}{\multicolumn{2}{|c|}{$\frac{\text { Mean differences }}{\text { (Site one-Site four) }}$}} \\
\hline & & & \multirow{2}{*}{$\begin{array}{l}\text { Site one } \\
\text { (no trees) }\end{array}$} & \multirow{2}{*}{$\begin{array}{l}\text { Site four } \\
\text { (beneath trees) }\end{array}$} & & \\
\hline & & & & & Value & $\begin{array}{l}\text { Std. } \\
\text { Deviation }\end{array}$ \\
\hline \multirow[t]{6}{*}{ Cloudy and cool } & 17 & $\operatorname{Max} \operatorname{Ta}\left({ }^{\circ} \mathrm{C}\right)$ & $18.9-28.0$ & $18.3-25.5$ & 1.8 & 0.7 \\
\hline & 17 & Min Ta $\left({ }^{\circ} \mathrm{C}\right)$ & $9.7-20.1$ & $9.7-19.9$ & 0.1 & 0.2 \\
\hline & 17 & Ave. Ta $\left({ }^{\circ} \mathrm{C}\right)$ & $16.0-22.9$ & $15.5-21.9$ & 0.8 & 0.2 \\
\hline & 17 & Max. RH (\%) & $79-97$ & $79-98$ & -1 & 0.8 \\
\hline & 17 & Min. RH (\%) & $43-83$ & $48-84$ & -4 & 2.4 \\
\hline & 17 & Ave. RH (\%) & $62-92$ & $64-94$ & -3 & 0.8 \\
\hline \multirow[t]{6}{*}{ Cloudy and hot } & 7 & $\operatorname{Max} \mathrm{Ta}\left({ }^{\circ} \mathrm{C}\right)$ & $28.3-36.8$ & $25.2-33.7$ & 3.2 & 0.5 \\
\hline & 7 & Min $\mathrm{Ta}\left({ }^{\circ} \mathrm{C}\right)$ & $13.3-19.0$ & $13.4-18.7$ & 0.0 & 0.3 \\
\hline & 7 & Ave. Ta $\left({ }^{\circ} \mathrm{C}\right)$ & $22.6-29.3$ & $21.3-27.8$ & 1.5 & 0.2 \\
\hline & 7 & Max. RH (\%) & $81-96$ & $82-98$ & 0 & 1.4 \\
\hline & 7 & Min. RH (\%) & $28-50$ & $33-57$ & -6 & 1.3 \\
\hline & 7 & Ave. RH (\%) & $49-70$ & $51-75$ & -3 & 1.4 \\
\hline \multirow[t]{6}{*}{ Total } & 43 & $\operatorname{Max} \operatorname{Ta}\left({ }^{\circ} \mathrm{C}\right)$ & $18.9-36.8$ & $17.9-33.7$ & 2.4 & 0.9 \\
\hline & 43 & $\operatorname{Min} \mathrm{Ta}\left({ }^{\circ} \mathrm{C}\right)$ & $9.7-20.1$ & $9.7-19.9$ & 0.1 & 0.2 \\
\hline & 43 & Ave. Ta $\left({ }^{\circ} \mathrm{C}\right)$ & $16.0-29.3$ & $15.2-27.8$ & 1.0 & 0.4 \\
\hline & 43 & Max RH (\%) & $79-97$ & 79-98 & 0.0 & 1.2 \\
\hline & 43 & Min RH (\%) & $28-83$ & $33-84$ & -5 & 2.3 \\
\hline & 43 & Ave. RH (\%) & $49-92$ & $51-94$ & -3 & 1.2 \\
\hline
\end{tabular}




$$
\text { a } \frac{1}{K} \sum_{d=1}^{K} \text { (Features on daily basis) }
$$

Where: $\mathrm{d}$ is the index of observation day $(\mathrm{d}=1, \ldots, \mathrm{K}), \mathrm{K}=17$ for cloudy and cool days and 7 for clear and hot days

\section{Appendix 2 Summarize table on daytime Ta and RH between cloudy and cold and clear and mild days in the daytime of winter}

\begin{tabular}{|c|c|c|c|c|c|c|}
\hline \multirow[t]{3}{*}{ Weather } & \multirow[t]{3}{*}{ No. of days } & \multirow[t]{3}{*}{ Features } & \multicolumn{2}{|c|}{ Features on daily basis ${ }^{\mathrm{a}}$} & \multirow{2}{*}{\multicolumn{2}{|c|}{$\frac{\text { Mean differences }}{\text { (Site one-Site four) }}$}} \\
\hline & & & \multirow{2}{*}{$\begin{array}{l}\text { Site one } \\
\text { (no trees) }\end{array}$} & \multirow{2}{*}{$\begin{array}{l}\text { Site four } \\
\text { (beneath trees) }\end{array}$} & & \\
\hline & & & & & Value & $\begin{array}{l}\text { Std. } \\
\text { Deviation }\end{array}$ \\
\hline \multirow[t]{6}{*}{ Cloudy and cold } & 11 & $\operatorname{Max} \operatorname{Ta}\left({ }^{\circ} \mathrm{C}\right)$ & $-2.2-4.6$ & $-2.7-3.9$ & 0.6 & 0.1 \\
\hline & 11 & $\operatorname{Min} \mathrm{Ta}\left({ }^{\circ} \mathrm{C}\right)$ & $-4.2-2.0$ & $-4.9-1.6$ & 0.5 & 0.2 \\
\hline & 11 & Ave. Ta $\left({ }^{\circ} \mathrm{C}\right)$ & $-3.2-3.3$ & $-3.9-2.8$ & 0.6 & 0.1 \\
\hline & 11 & Max. RH (\%) & $89-96$ & $90-98$ & -1.8 & 0.4 \\
\hline & 11 & Min. RH (\%) & $79-94$ & $81-96$ & -2.2 & 0.6 \\
\hline & 11 & Ave. RH (\%) & $83-95$ & $85-97$ & -2.0 & 0.4 \\
\hline \multirow[t]{6}{*}{ Clear and mild } & 6 & $\operatorname{Max} \mathrm{Ta}\left({ }^{\circ} \mathrm{C}\right)$ & $7.6-13.4$ & $7.4-12.7$ & 0.5 & 0.2 \\
\hline & 6 & $\operatorname{Min} \mathrm{Ta}\left({ }^{\circ} \mathrm{C}\right)$ & $0.2-4.4$ & $0.4-4.3$ & 0.1 & 0.2 \\
\hline & 6 & Ave. Ta $\left({ }^{\circ} \mathrm{C}\right)$ & $5.1-10.3$ & $4.9-9.6$ & 0.5 & 0.2 \\
\hline & 6 & Max. RH (\%) & $86-96$ & $87-96$ & -1 & 0.6 \\
\hline & 6 & Min. RH (\%) & $55-78$ & $58-80$ & -3 & 1.4 \\
\hline & 6 & Ave. RH (\%) & $66-83$ & $69-84$ & -3 & 0.9 \\
\hline \multirow[t]{6}{*}{ Total } & 58 & $\operatorname{Max} \operatorname{Ta}\left({ }^{\circ} \mathrm{C}\right)$ & $-2.2-13.4$ & $-2.7-12.9$ & 0.5 & 0.2 \\
\hline & 58 & $\operatorname{Min} \mathrm{Ta}\left({ }^{\circ} \mathrm{C}\right)$ & $-4.2-10.3$ & $-4.9-10.2$ & 0.2 & 0.2 \\
\hline & 58 & Ave. Ta $\left({ }^{\circ} \mathrm{C}\right)$ & $-3.2-11.4$ & $-3.9-11.2$ & 0.5 & 0.2 \\
\hline & 58 & Max RH (\%) & $68-97$ & $69-98$ & -1 & 0.6 \\
\hline & 58 & Min RH (\%) & $55-94$ & $58-96$ & -2 & 1.0 \\
\hline & 58 & Ave. RH (\%) & $62-95$ & $63-97$ & -3 & 0.6 \\
\hline
\end{tabular}

a $\frac{1}{K} \sum_{d=1}^{K}$ (Features on daily basis)

Where: $\mathrm{d}$ is the index of observation day $(\mathrm{d}=1, \ldots, \mathrm{K}), \mathrm{K}=11$ for cloudy and cool days and 6 for clear and hot days 
Appendix 3 Summary on the comparison of $24 \mathrm{~h}$ Ta and wind between the $\mathrm{CU}$ and NT conditions of selected days

\begin{tabular}{|c|c|c|c|c|}
\hline \multirow[t]{2}{*}{ Days } & \multirow[t]{2}{*}{ Features } & \multicolumn{2}{|c|}{ Values (Range of receptors) } & \multirow{2}{*}{$\begin{array}{l}\text { Differences }^{\mathrm{a}} \\
\text { NT-CU (SD) }\end{array}$} \\
\hline & & Current (CU) & No tree $(\mathrm{NT})$ & \\
\hline \multirow[t]{3}{*}{ 2nd Aug, 2013 clear and hot } & $\operatorname{Max} \operatorname{Ta}\left({ }^{\circ} \mathrm{C}\right)$ & $33.6-34.9^{c}$ & $34.7-36.0$ & $1.1(0.23)$ \\
\hline & Min. Ta $\left({ }^{\circ} \mathrm{C}\right)$ & $19.6-20.3^{\mathrm{c}}$ & $19.6-20.3$ & $0.0(0.03)$ \\
\hline & Ave. Ta $\left({ }^{\circ} \mathrm{C}\right)$ & $26.4-26.9^{c}$ & $26.9-27.4$ & $0.5(0.04)$ \\
\hline \multirow[t]{3}{*}{ 3rd Aug, 2013 clear and cool } & $\operatorname{Max} \operatorname{Ta}\left({ }^{\circ} \mathrm{C}\right)$ & $24.7-26.2^{\mathrm{c}}$ & $24.8-26.3$ & $0.2(0.05)$ \\
\hline & Min. Ta $\left({ }^{\circ} \mathrm{C}\right)$ & $20.5-21.1^{\mathrm{c}}$ & $20.5-21.1$ & $0.0(0.03)$ \\
\hline & Ave. Ta $\left({ }^{\circ} \mathrm{C}\right)$ & $22.4-23.2^{\mathrm{c}}$ & $22.5-23.3$ & $0.1(0.03)$ \\
\hline \multirow[t]{3}{*}{ 18th Jan, 2014 clear and mild } & $\operatorname{Max} \operatorname{Ta}\left({ }^{\circ} \mathrm{C}\right)$ & $8.5-9.4^{\mathrm{d}}$ & $8.6-9.5$ & $0.2(0.05)$ \\
\hline & Min. Ta $\left({ }^{\circ} \mathrm{C}\right)$ & $5.8-6.3^{\mathrm{d}}$ & $5.8-6.3$ & $0.0(0.05)$ \\
\hline & Ave. Ta $\left({ }^{\circ} \mathrm{C}\right)$ & $6.7-7.2^{\mathrm{d}}$ & $6.7-7.2$ & $0.1(0.02)$ \\
\hline \multirow[t]{3}{*}{21 st Jan, 2014 cloudy and cold } & $\operatorname{Max} \mathrm{Ta}\left({ }^{\circ} \mathrm{C}\right)$ & $2.3-2.7^{\mathrm{d}}$ & $2.3-2.7$ & $0.0(0.02)$ \\
\hline & Min. Ta $\left({ }^{\circ} \mathrm{C}\right)$ & $1.2-1.5^{\mathrm{d}}$ & $1.2-1.5$ & $0.0(0.02)$ \\
\hline & Ave. Ta $\left({ }^{\circ} \mathrm{C}\right)$ & $1.7-2.1^{\mathrm{d}}$ & $1.7-2.1$ & $0.0(0.01)$ \\
\hline
\end{tabular}

a $\frac{1}{M} \sum_{j=1}^{M}\left(D F c u_{j}-D F n t_{j}\right)$

Where: $\mathrm{j}$ is the index of receptors $(\mathrm{j}=1, \ldots, \mathrm{M}) ; \mathrm{M}=68$

${ }^{\mathrm{b}} \mathrm{SD}(\mathrm{SD})$ is given in parenthesis

c $5 \%$ mixed tree cover in the summer

d $3 \%$ evergreen tree cover in the winter 
Appendix 4 Comparisons of average value (a), CR (b) and TR (c) of Ta between $C U$ and NT conditions on 2nd august, 2013.
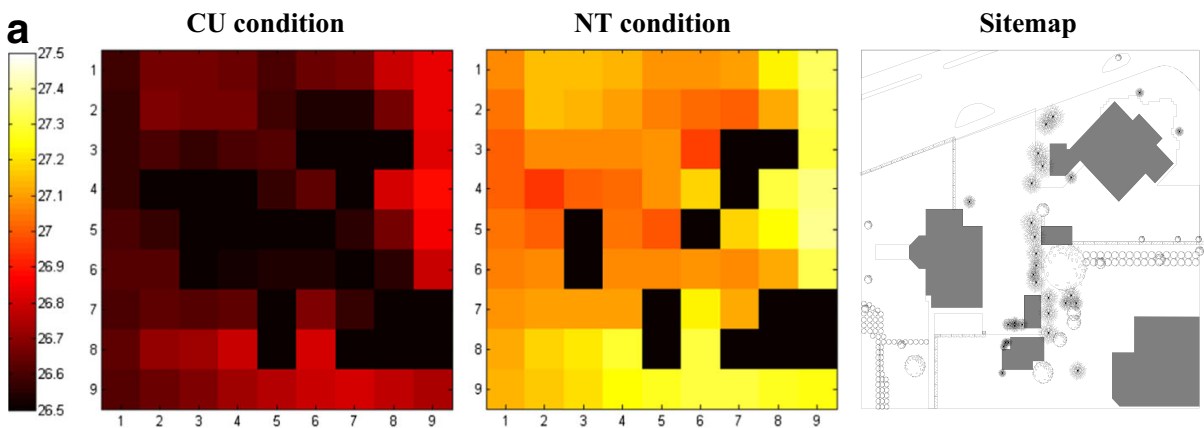

b
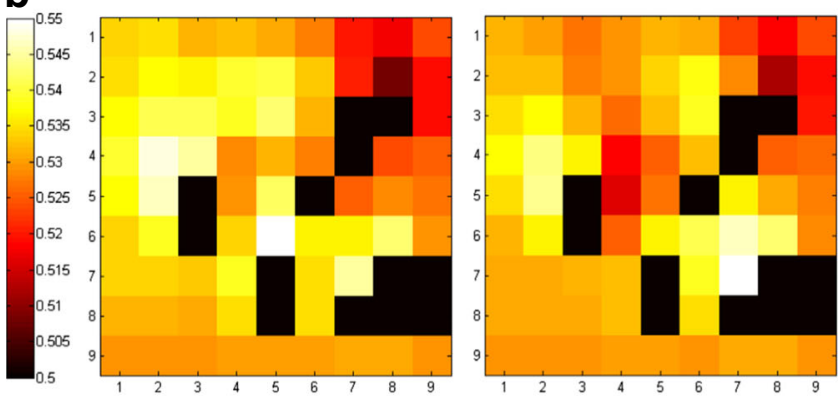

C
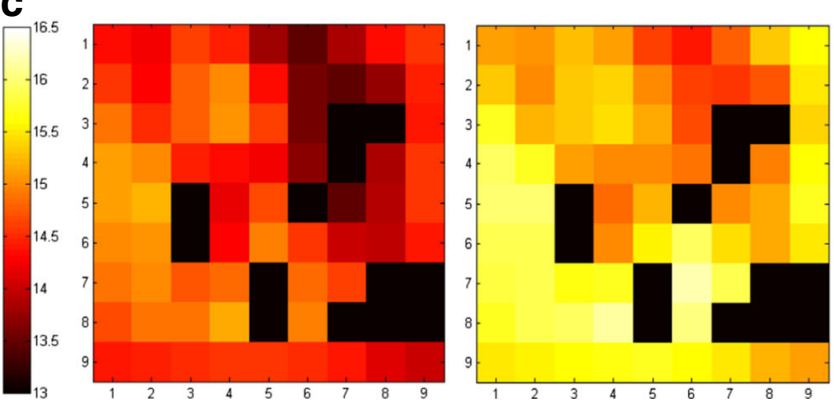
Appendix 5 PMV value (at $1.5 \mathrm{~m}$ height) at $14: 00$ on $2^{\text {nd }}$ and $3^{\text {rd }}$ August, 2013 under CU (left) and NT (right) trees

Days

$2^{\text {nd }}$ August, 2013
clear and hot

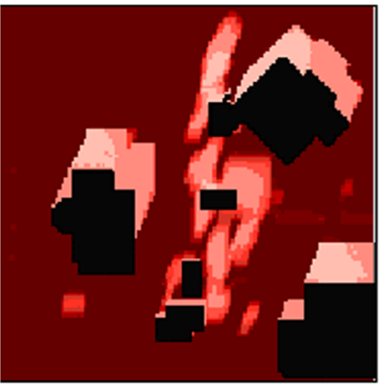

$3^{\text {rd }}$ August, 2013

cloudy and cool

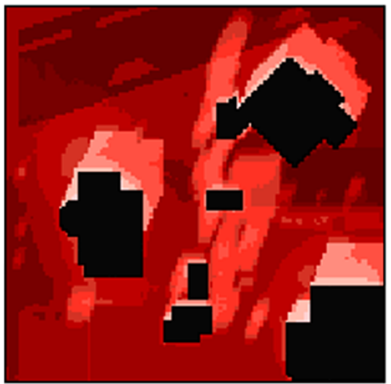

$18^{\text {th }}$ January, 2014 clear and mild

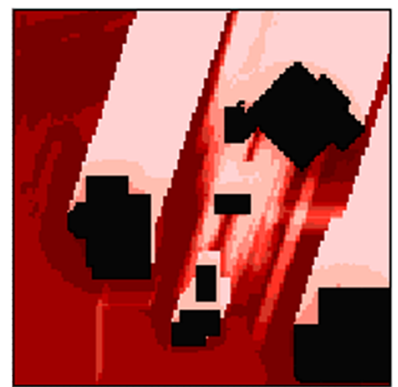

$21^{\text {st }}$ January, 2014 cloudy and cold
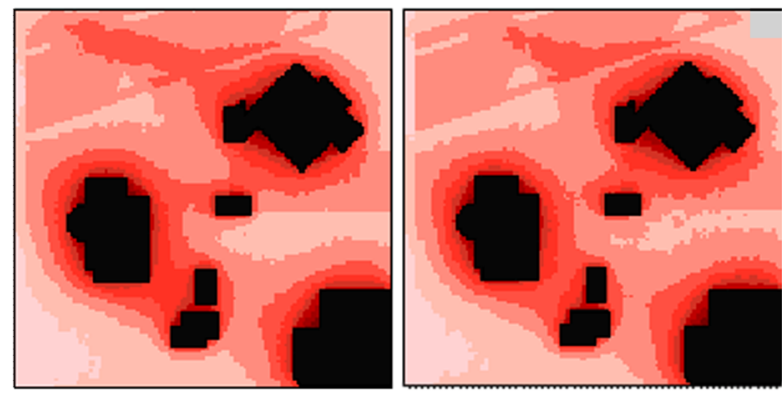

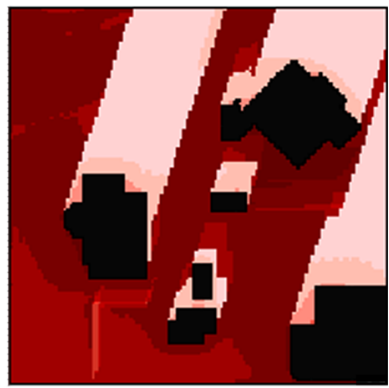

No tree (NT)

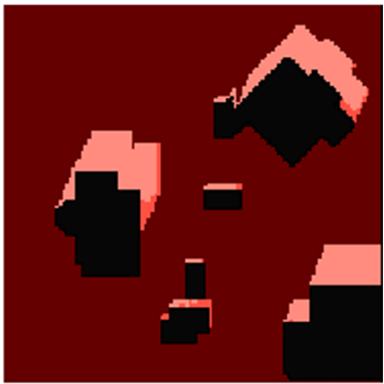

PMV Value
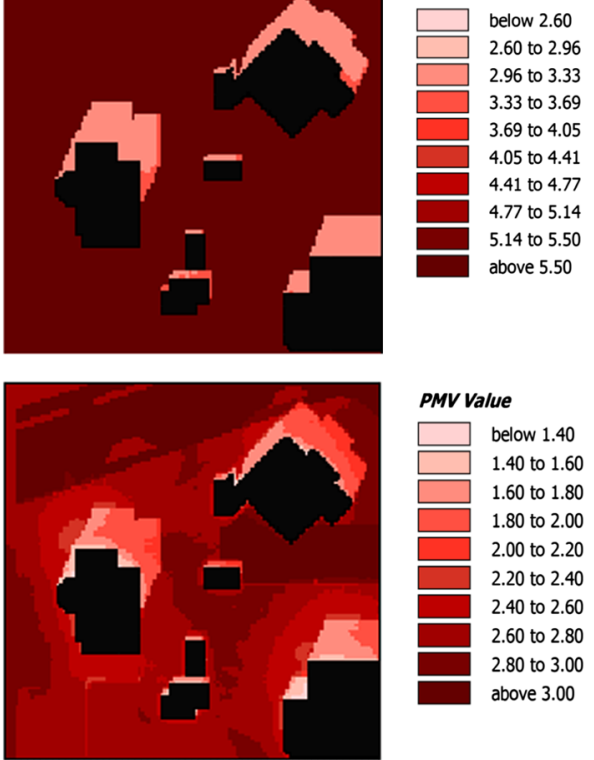

\section{PMV Value}

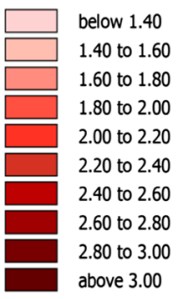

PMV Value

$\square$ below 0.45 0.45 to 0.55

0.55 to 0.65 0.65 to 0.75

0.75 to 0.85

0.85 to 0.95

0.95 to 1.05

1.05 to 1.15

1.15 to 1.25

above 1.25

\section{PMV Value}

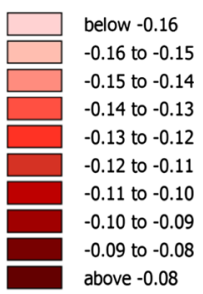

- Definition: color graphics 
Appendix 6 PMV value (at $1.5 \mathrm{~m}$ height) at 22:00 on $2^{\text {nd }}$ and $3^{\text {rd }}$ August, 2013 under CU (left) and NT (right) conditions

Days

$2^{\text {nd }}$ August, 2013
clear and hot

$3^{\text {rd }}$ August, 2013

cloudy and cool

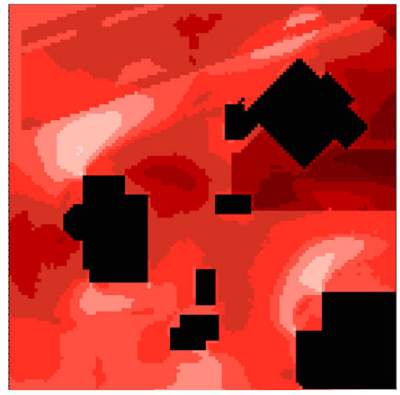

$18^{\text {th }}$ January, 2014 clear and mild

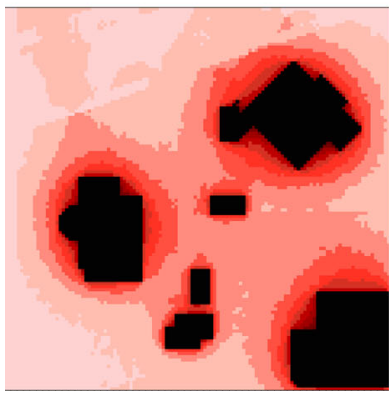

$21^{\text {st }}$ January, 2014 cloudy and cold

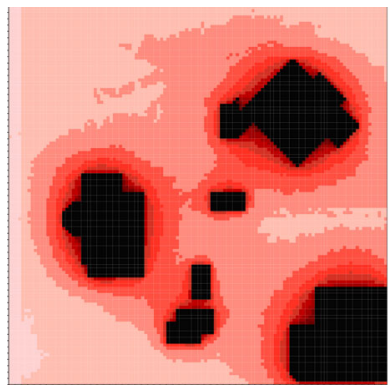

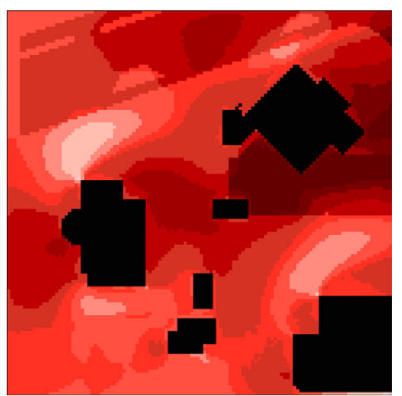

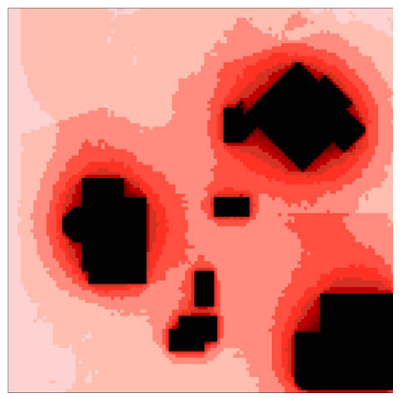

No tree (NT)

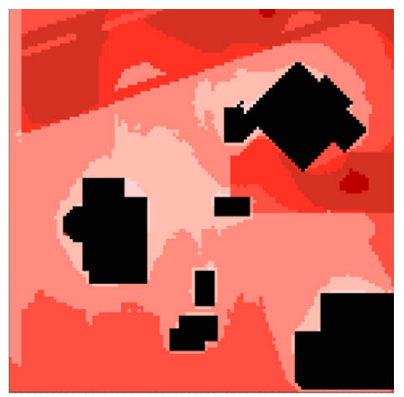

PMV Value

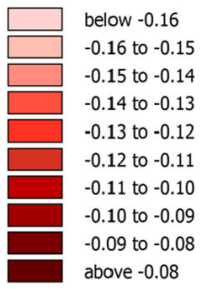

PMV Value

$\square$ below 0.08 0.08 to 0.12 0.12 to 0.16 0.16 to 0.20 0.20 to 0.24 0.24 to 0.28 0.28 to 0.32 0.32 to 0.36 0.36 to 0.40 above 0.40

\section{PMV Value}
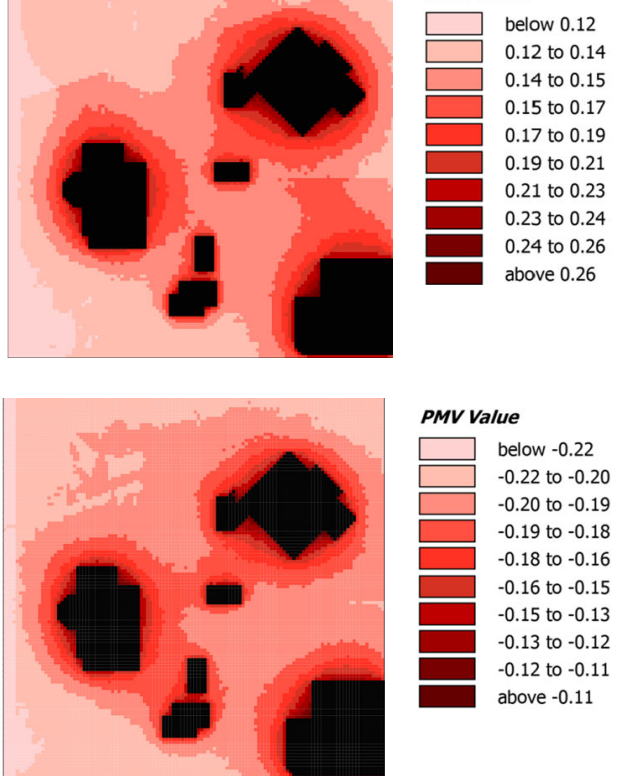

PMV Value

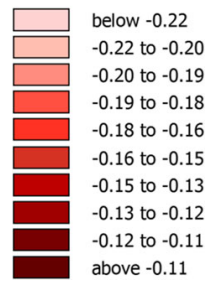


Open Access This article is distributed under the terms of the Creative Commons Attribution License which permits any use, distribution, and reproduction in any medium, provided the original author(s) and the source are credited.

\section{References}

Akbari H (2002) Shade trees reduce building energy use and CO2 emissions from power plants. Environ Pollut 116:S119-126. Retrieved from http://www.ncbi.nlm.nih.gov/pubmed/11833899

Akbari H, Pomerantz M, Taha H (2001) Cool surfaces and shade trees to reduce energy use and improve air quality in urban areas. Sol Energy 70(3):295-310. doi:10.1016/S0038-092X(00)00089-X

Berry R, Livesley SJ, Aye L (2013) Tree canopy shade impacts on solar irradiance received by building walls and their surface temperature. Build Environ 69:91-100. doi:10.1016/j.buildenv.2013.07.009

Bonan GB (2002) Ecological climatology : concepts and applications (p. 678 pp). Cambridge University Press, Cambridge

Bruse M (2010) ENVI-met 3.1: Updated model overview. Bochum, Germany. Retrieved from http://www.envimet.com

Chen WY, Jim CY (2008) Assessment and valuation of the ecosystem services provided by urban forests. In: Carreiro MM, Song YC, Wu J (eds) Ecology, planning, and management of urban forests: international perspectives. Springer, New York, pp 53-83

Emmanuel R, Rosenlund H, Johansson E (2007) Urban shading - a design option for the tropics? A study in Colombo, Sri Lanka. J Climatol 27:1995-2004. doi:10.1002/joc.1609

Fahmy M, Sharples S, Eltrapolsi A (2009) Dual stage simulations to study the microclimatic effects of trees on thermal comfort in a residential building, Cairo, Egypt. In: Eleventh International IBPSA Conference. Building Simulation, Glasgow, pp 1730-1736

Frelich LE (1992) Predicting dimensional relationship for twin cities shade trees. Department of Forest Resources, University of Minnesota, St. Paul, MN

Hedquist BC, Brazel AJ (2014) Seasonal variability of temperatures and outdoor human comfort in Phoenix, Arizona, U.S.A. Build Environ 72:377-388. doi:10.1016/j.buildenv.2013.11.018

Heisler GM, Grant RH (2000) Ultraviolet radiation in urban ecosystems with consideration of effects on human health. Urban Ecosyst 4:193-229

Huang L, Li J, Zhao D, Zhu J (2008) A fieldwork study on the diurnal changes of urban microclimate in four types of ground cover and urban heat island of Nanjing, China. Build Environ 43(1):7-17. doi:10.1016/j. buildenv.2006.11.025

ISO 7726 (1998) Ergonomics of the thermal environment - instruments for measuring physical quantities. International Standard Organization, Geneva

Kuye A, Jagtap SS (1992) Analysis of solar radiation data for port harcourt, Nigeria. Sol Energy 49(2):135-145

Lalic B, Mihailovic DT (2004) An empirical relation describing Leaf-Area Density inside the forest for environmental modeling. J Appl Met Clim 43(4):641-645

Matzarakis A, Mayer H (1998) Investigations of urban climate's thermal component in Freiburg, Germany. In: Preprints second urban environment symposium - 13th conference on biometeorology and aerobiology. American Meteorological Society, Albuquerque, pp 140-143

Mcpherson EG, Herrington LP, Heisler GM (1988) Impacts of vegetation on residential heating and cooling. Energy Build 12:41-51

McPherson EG, Simpson JR, Livingston M (1989) Effects of three landscape treatments on residential energy and water use in Tucson, Arizona. Energy Build 13:127-138

Middel A, Häb K, Brazel AJ, Martin CA, Guhathakurta S (2014) Impact of urban form and design on midafternoon microclimate in Phoenix Local Climate Zones. Landsc Urban Plan 122:16-28. doi:10.1016/j. landurbplan.2013.11.004

MA - Millennium Ecosystem Assessment (2005) Ecosystems and human well-being: synthesis. Island Press, Washington

Morakinyo TE, Balogun AA, Adegun OB (2013) Comparing the effect of trees on thermal conditions of two typical urban buildings. Urban Clim 3:76-93. doi:10.1016/j.uclim.2013.04.002

Park M, Hagishima A, Tanimoto J, Narita K (2012) Effect of urban vegetation on outdoor thermal environment: field measurement at a scale model site. Build Environ 56:38-46. doi:10.1016/j.buildenv.2012.02.015

Peng L, Jim C (2013) Green-roof effects on neighborhood microclimate and human thermal sensation. Energies 6(2):598-618. doi:10.3390/en6020598 
Shahidan MF, Jones PJ, Gwilliam J, Salleh E (2012) An evaluation of outdoor and building environment cooling achieved through combination modification of trees with ground materials. Build Environ 58:245-257. doi: 10.1016/j.buildenv.2012.07.012

Skoulika F, Santamouris M, Kolokotsa D, Boemi N (2014) On the thermal characteristics and the mitigation potential of a medium size urban park in Athens, Greece. Landsc Urban Plan 123:73-86. doi:10.1016/j. landurbplan.2013.11.002

Taha H, Akbari H, Rosenfeld A (1991) Heat island and oasis effects of vegetative canopies: micrometeorological field-measurements. Theor Appl Climatol 44:123-138

Wang Y, Bakker F, de Groot R, Wörtche H (2014) Effect of ecosystem services provided by urban green infrastructure on indoor environment: a literature review. Build Environ 77:88-100. doi:10.1016/j.buildenv. 2014.03.021

Willmott CJ (1981) On the validation of models. Phys Geogr 2:184-194 